\title{
Svakodnevni život: sučelje mikro, mezo i makroteorija
}

\author{
Hajrudin Hromadžić \\ Sveučilište u Rijeci, Filozofski fakultet, Hrvatska \\ e-mail: hhromadzic@ffri.hr
}

SAŽETAK Rad je posvećen preglednom prikazu nekih od najrelevantnijih teorija svakodnevnog života. Shodno tomu, u članku su tematizirane sve tri razine teorija svakodnevice - mikro (Garfinkel, Simmel, Goffman), mezo (Berger, Luckmann, Bourdieu) i makro (Lefebvre, Debord, Vaneigem, Heller) - pri čemu je sociologija, kao središnja društveno-humanistička disciplina po pitanju tema i fenomena svakodnevnog života, dovedena u predmetno-metodološki i interdisciplinarni dijalog s filozofijom, a rubno is antropologijom te kulturalnim studijima. U radu se pokušala dovesti u pitanje, štoviše i osporiti, nerijetko zastupana teza o samorazumljivoj primarnosti mikrosocioloških teorija pri istraživanjima i interpretacijama svakodnevnog života u odnosu na makroteorijska promišljanja svakodnevlja i njihovu relevantnost.

Ključne riječi: svakodnevni život, mikrosociologija svakodnevice, makroteorije svakodnevlja. 


\section{Uvod}

Bez obzira na činjenicu da društveno-humanistički znanstveni interesi za proučavanja fenomenâ svakodnevnog života traju već desetljećima - pokrivaju, naime, gotovo cijelo 20. stoljeće, a traju sve do danas - čini se da početni epistemološki izazovi na tom području ostaju nepromijenjeni i moguće ih je svesti na nekoliko bazičnih pitanja: kako u nesagledivo širokoj paleti pojavnosti, situacija i fenomena koji tvore tkivo, gustu, neproničnu tamnu masu življenog zvanu „svakodnevni život“ razlučiti ono što ćemo definirati i istraživački tretirati kao znanstveno relevantno od onog što ne zavrjeđuje taj status; koje bi bile adekvatne istraživačke metode za takav pothvat; koje su se teorije u međuvremenu pokazale primjerenim okvirima za takav zadatak? Štoviše, riječima nekih drugih autora, „postoji li nešto što karakterizira perspektivu svakodnevnog života kao distinktivnu teorijsku cjelinu?" (Adler, Adler i Fontana, 1987.:218).

Uzevši u obzir da je nastanak znanstveno-problemskog tropa "svakodnevni život“ u povijesnom smislu neodvojiv od šireg konteksta fenomena koje podvodimo pod pojmove industrijalizacije, urbanizacije i modernizacije, odnosno od iskustava epohe moderne od 19. stoljeća nadalje, može biti razumljivo da ga se često - i opravdano dovodi u blisku korelaciju sa spomenutim paradigmama. Razdioba svakodnevice na radno i neradno, a potom i slobodno vrijeme, to jest dokolicu; društveno otuđenje u tvornički mehaniziranom radnom procesu; standardizacija satnog računanja vremena u organizaciji rada i života; repetitivnost života „iz dana u dan“, koja je presliku takvog doživljaja svakodnevnog pronašla u zaštitnom znaku fordističko-tejlorističke industrije - tekućoj traci (više u Highmore, 2002.:5-11); ali i sveopća rutina te s time povezani osjećaji monotonije i dosade; novi tipovi društvenih iskustava u okruženju velegrada; administrativno-birokratsko uređenje društva do kafkijanskih dimenzija apsurda... sve je to bitno odredilo percepciju svakodnevice ranog modernog društva.

Tako široko postavljenim problemskim aspektima mogli bismo istraživački pristupiti preko sveprisutnog pojma znanstvene interdisciplinarnosti, koji bez obzira na raširenost i ne nužno uvijek primjerenu i preciznu epistemološku upotrebu na polju fenomena svakodnevnog života nalazi punu opravdanost svoje primjene, pa i do te mjere da ovoj temi omogućuje i dodatni iskorak, onaj u sferu tzv. transdisciplinarnosti. Naime, već je u ranoj fazi akademskih interesa za proučavanja svakodnevnog života postalo jasno da središnja disciplina po pitanju tog problemskog motiva - sociologija ${ }^{1}$ - treba ući u suradnički dijalog sa srodnim joj društveno-humanističkim pristupi-

${ }^{1}$ Neki od ranih socioloških radova koji su sumirali dotadašnje istraživačko-teorijske doprinose ovoj temi jesu, primjerice, knjige Truzzija (1968.), Douglasa (1971.) te Birenbauma i Sagarina (1973.). 
ma kako bi se mogli polučiti produktivni istraživački rezultati. ${ }^{2}$ Stoga je razumljivo da takva predmetna i metodološka isprepletenost po pitanju istraživanja fenomena svakodnevice podrazumijeva i posezanje u riznice sociologiji bliskih disciplina kako bi se tamo pronašle prikladne i uporabne konceptualne alatke, koje bi potom mogle biti iskorištene za adekvatnu znanstvenu aplikaciju u analizi svakodnevno-životne društvene zbilje. Takva teorijsko-empirijska istraživačka putanja iscrtala je doista širok interdisciplinarni luk. Jasno se uvidjelo da je, pored bogatog nasljeđa same sociologi$\mathrm{je}^{3}$, adekvatnu konceptualnu aparaturu za proučavanja svakodnevnog života moguće pronaći u rasponu od različitih pravaca u filozofiji ${ }^{4}$, preko povijesti ${ }^{5}$, pa do antropolo-

$\mathbf{2}$ To je ponajviše došlo do izražaja u sociološko-antropološkoj razmjeni metoda kada su istraživanja svakodnevnog života u pitanju. Naime, klasična antropološka metoda etnografije upravo je preko područja svakodnevnog života dobro primljena u sociologiji, dok je istovremeno uobičajena sociološka kvantitativno istraživačka metoda ankete našla svoje mjesto u antropologiji, uglavnom u funkciji preliminarnih istraživanja prilikom priprema za izlazak na teren. Predmetna preklapanja još su i izrazitija, prepoznajemo ih u velikom fundusu sadržaja koji se tretiraju kao fenomeni suvremenog društva: urbana plemena, subkulture, životni stilovi i identiteti, iskustva velegrada i tomu slično.

3 Gotovo svaki osvrt na povijesnu perspektivu socioloških analiza svakodnevnog života redovito započinje s općim mjestom, čikaškom školom simboličkog interakcionizma, pri čemu je naglasak na tezama Ervinga Goffmana iz 1950-ih i 1960-ih godina, te s kalifornijskom tradicijom etnometodoloških istraživanja, u kojoj je Harold Garfinkel najprepoznatljivija figura. Neizostavna je referenca i Georg Simmel, njegovi tekstovi/eseji s kraja 19. i početka 20. stoljeća. Svima njima ćemo se u članku uskoro vratiti. Istovremeno iznenađuje da literatura donekle zanemaruje važnog autora na ovu temu, klasičnog sociologa iz prve polovice 20. stoljeća, Norberta Eliasa. Ovdje nam je prvenstveno značajna Eliasova studija O procesu civilizacije iz 1939. godine, u kojoj autor, nezadovoljan mnogostrukošću i neodređenošću značenja koja se pripisuju terminu „svakodnevno“, izrađuje „Tabelu rekonstruiranih implicitnih značenja pojmova svakodnevnog života“, u kojoj pojmu „svakodnevica“ i njemu pripisanim značenjima suprotstavlja pojam „praznik“ (Elias, 1996.). Tako je pod pojam „svakodnevica“ svrstao implicitna značenja kao što su: rutina, radni dan, privatni život, repetitivnost, prirodnost, spontanost..., dok je kontrapunkt, imenovan „praznik“, prema Eliasu ispunjen značenjima kakva su: buržoaski život, nerutiniziranost, javni ili profesionalni život, sfera umjetnog, nespontanog... Takva tipologizacija Eliasu služi kako bi izveo bazičniju podjelu u shvaćanju svakodnevice, razliku između njezinog formalnog i supstantivnog razumijevanja (više u Spasić, 2004.:38-41). Pojačanom diverzifikacijom socioloških studija svakodnevnog života u 1980-im još će neki pravci, primjerice egzistencijalna sociologija, sociologija emocija ili konverzacijska analiza, dobiti zapažena mjesta u ovom kontekstu.

${ }^{4}$ Filozofija je dala nemjerljiv doprinos fundamentalnim proučavanjima svakodnevnog života. To se odnosi na klasična mjesta poput filozofijske fenomenologije (naročito Husserl i njegov koncept „svijet života“/Lebenswelt, koji će imati ključan utjecaj na fenomenološku sociologiju, točnije Alfreda Schütza i njegovo širenje Husserlovog „svijeta života“ na koncept „svakodnevnog svijeta života“), egzistencijalizam (Heidegger, Sartre, Merleau-Ponty) i filozofiju jezika (Wittgenstein). No filozofijska će nas proučavanja svakodnevnog života u nastavku članka posebice zanimati u kontekstu (neo)marksističkih teorija Lefebvrea, Heller i situacionista, odnosno njihovog doprinosa makroperspektivama svakodnevice.

5 Za istraživanja fenomenâ svakodnevice iz perspektive povijesti svakako je najznačajnija čuvena francuska Škola Anala (Annales), odnosno rad francuskih historiografa, povjesničara okupljenih oko časopisa Annales d'histoire économique et sociale 1929. godine, s Fernardom Braudelom kao središnjim autoritetom u ovom kontekstu. Pored nje, u ovom je kontekstu značajno spomenuti i „povijest svakodnevnog života“ (Alltagsgeschichte) ili tzv. Bilefeldsku školu u Njemačkoj iz sredine 1970-ih, s Lüdtkeom i Medickom kao najznačajnijim predstavnicima. Svoj je doprinos svakako dala i talijanska škola mikrohistorije (pogotovo Ginzburg i Levi), što je imalo naročit odjek kod povjesničara koji se bave ranim novovjekovljem. 
gije $^{6}$ i etnologije 7 . Obiljě̌ja predmetno-metodološke bliskosti, kada je riječ o svakodnevnom životu kao problemskom motivu, dobro reprezentira dihotomija koju Ivana Spasić definira kao govor $o$ svakodnevnom na jednoj strani - u kojem „svakodnevni život postaje još jedan predmet na koji se primenjuju već ustaljene i oprobane procedure sociološkog mišljenja i proučavanja" - te govor $i z$ svakodnevnog na drugoj strani, gdje „okretanje svakodnevnom životu postaje povod da se same te procedure iznova promisle. Uvod u kontekstualizovanost i svakodnevno utemeljenje celokupnog ljudskog znanja koristi se za podrivanje pozitivističkih pretenzija" (Spasić, 2004.:10). Doista, ne samo da je došlo do „podrivanja pozitivističkih pretenzija“ prilikom znanstvenih napora da se protumače intrigantni aspekti svakodnevice već se pritom jasno artikulirala i postpozitivistička teza da je nemoguće, posebice kada govorimo o fenomenima društvenog svijeta, napraviti jasnu distinkciju između pozicije promatrača/ istraživača i onog što se promatra/istražuje, to jest da je potrebno nadići pozitivistički postulat o distanci između aktivnog spoznajnog subjekta i pasivnog spoznavajućeg objekta. ${ }^{8}$ Bio je to presudan spoznajni iskorak ka znanstvenom utemeljenju istraživa-

6 Antropološka proučavanja svakodnevnog života postaju moguća $s$ „velikim obratom“ u antropologiji u drugoj polovici 20. stoljeća, koji direktno korelira s paradigmom postkolonijalnog, ali i s razdobljem etabliranja postpozitivističke epistemologije. Konkretno, to znači da se klasični, početni antropološki motivi proučavanja - evidentno oblikovani u duhu kolonijalizma kasnog 19. i ranog 20. stoljeća - na primjer kolonijalni „drugi“ i/li „primitivne kulture“, sa spomenutim razdobljem druge polovice 20. stoljeća nadopunjuju istraživačkim interesima za ono neposredno, svakodnevno životno, urbano okruženje tzv. prvog svijeta, odnosno samo antropologovo ishodište, svijet iz kojega dolazi. Takav pomak u suvremenoj antropologiji od 1970-ih godina nadalje učinit će da pod njen interes potpadnu ,rubne“ svakodnevno životne teme i motivi, na primjer fenomeni beskućništva, alkoholizma, boemskog života, konzumerizma ili prostori poput urbanih vrtova, kockarnica, aerodroma i supermarketa (vidi, primjerice, Sulima, 2005.; Augé, 2005.). Takva antropologija svakodnevnog života ući će u direktnu, već spomenutu predmetnoistraživački plodonosnu suradnju sa suvremenim pravcima u sociologiji (recimo Goffmanovim istraživanjima), ne samo onoj svakodnevnog života već i s, na primjer, sociologijom urbanog ili sociologijom životnih stilova, a istovremeno će se pristupima i tematski približiti (trans)disciplinama poput kulturalnih studija. Inače, stav kulturalnih studija o svakodnevnom životu najopćenitije se može smjestiti u kontekst i optiku tzv. Birminghemske škole po pitanju preusmjeravanja naglasaka u percepciji, interpretaciji i značenju kulture od one „ekskluzivne, elitne i visoke“ ka „inkluzivnoj, pučkoj, narodnoj“.

${ }^{7}$ U svojim počecima etnologija svakodnevice bila je temeljena na kulturalno povijesnoj metodi istraživanja tradicijske seljačke kulture i njezinog „svagdana“ (još jedan pojam koji se koristi za svakodnevicu, označavajući razliku radnog dana od blagdana i praznika), a od od 70-ih i 80-ih godina 20. stoljeća započinju sustavnija etnološka istraživanja urbane svakodnevice. To je imalo velik odjek i u etnologiji na prostoru Jugoslavije. Primjerice, u hrvatskoj etnologiji knjiga Dunje Rihtman Auguštin Etnologija naše svakodnevice ima pionirski značaj, potom i Ulice moga grada Aleksandre Muraj. U slovenskoj etnologiji takav je iskorak napravio Slavko Kremenšek, a u srpskoj etnologiji imamo cijeli niz studija nastalih u toj tradiciji, od utemeljiteljskih radova Cvetka Kostića pa sve do projekta Etnografskog instituta SANU „Etnološko istraživanje u urbanim sredinama“.

8 Zasade takvog tipa epistemološkog obrata, štoviše nove znanstvene paradigme, prepoznajemo još u kvantnoj teoriji fizike iz 1920-ih i 1930-ih, godina preciznije u tzv. Heisenbergovoj teoriji neodređenosti, koja je otvorila nove spoznaje u dotadašnjim proučavanjima atoma i ponudila tada radikalnu tezu prema kojoj putanja kruženja elektrona oko protonsko-neutronske jezgre atoma ovisi i o promatračevoj poziciji, to jest o točki pogleda u eksperimentu. 
nja svakodnevnog života. Stoga se može zaključiti da se kritika pozitivizma oblikovala u trenutku kada pozitivistička paradigma u društveno-humanističkim istraživanjima više nije mogla ponuditi uvjerljiva i prihvatljiva objašnjenja svijeta. Štoviše, ambicija da postoje mogućnosti iznalaženja neke tvrde zakonitosti u fenomenima društvenih svjetova izgledala je daljom nego ikada.

I uvid u teorije svakodnevice, također brojne i različite, također nam otvara prostor za tezu koja bi bila potencijalni odgovor na spomenutu epistemološku dilemu, kao i na pitanja postavljena s početka teksta: vrijednosno oblikovana pozicioniranost točaka pogledâ i interpretacijâ bit će važan kriterij prilikom odabira pojedinačnih teorijskoistraživačkih orijentacija. Konkretnije, hoće li partikularna znanstvena i teorijska orijentacija vidjeti u heterogenoj strukturi svakodnevnog života tek postmodernu igrivost - primjerice lukavost i prepredenost u vidu „decertauovskih“ taktika izmicanja i premještanja spram strateški pozicionirane moći (De Certeau, 2003.) - ili će pak u svakodnevici prepoznati potencijal za nešto više, doveden čak do ideja o radikalnoj društvenoj transformaciji, otporu i revoluciji, kako su to utopijski koncipirali, na primjer, neomarksistički orijentirani Lefebvre i situacionisti (prije svih Debord i Vaneigem), doista je problemsko pitanje koje mora uključiti varijablu ideologije, što je u popriličnoj suprotnosti sa suvremenim neoliberalnim trendovima u znanosti, neopozitivizmom i tehnokracijom u ime navodne znanstvene objektivnosti, ekspertnosti i stručnosti.

Istovremeno znamo i da su povijesno-društvene okolnosti od velike važnosti u smislu stvaranja kontekstualnih preduvjeta za istraživanja socijalnih fenomena, pa tako i svakodnevnog života. Primjerice urbani svakodnevno životni mikrofenomeni vezani uz bujanja svjetskih velegradova na prijelazu stoljeća (iz 19. u 20., tzv. fin de siècle), koji će zaintrigirati Simmela u okviru tada još uvijek mlade sociologije. Ili socijalne promjene koje su bitno okarakterizirale društva tzv. Zapada u 1960-im - sekularizam i ateizam u usponu, snaga lijevih političko-ideoloških ideja, bujanje heterogene pluralnosti identiteta (rodnih, seksualnih, kulturnih...), alternativno-životne kontrakulture, masovnost hipi subkulture, različiti mirovni, antiratni i ekološki pokreti... - uz istovremeno, već spomenuto, etabliranje znanstvenog postpozitivizma, ključno su doprinijeli kreiranju pretpostavki da motivi i tematike koji su postali problemska mjesta u proučavanjima svakodnevnog života dobiju svoje, istina alternativno ali prepoznatljivo, teorijskoistraživačko mjesto ${ }^{9}$. Ako to uzmemo u obzir, razumljivo je kako i zašto su znanstve-

9 Iako treba naglasiti da se u tom kontekstu teme i istraživanja koji tvore sukus problemskog polja svakodnevnog života kreću rubom, čak i vrlo prošireno poimane, epistemološke legitimacije. Naime, uz društveno-humanističke pristupe proučavanjima svakodnevnog života nerijetko se veže termin „,idolatrija“, ovdje izmješten iz svog primarnog religijskog konteksta i alociran u sferu postmodernog društva i kulture. To konkretno znači da se „'idolatrijski” pristupi svakodnevnom životu - pristupi koji obogotvoruju - oblikuju u osobenom ozračju savremenosti, naime u postmodernom duhu koji više ne veruje u racionalnost i univerzalnost, naročito zapadnu, u nauku i tehniku, u metodologiju, u 'istinu'“ (Spasić, 2004.:215). 
no-institucionalne kolijevke sociologije svakodnevnog života iz tog razdoblja locirane upravo u okruženju liberalno-alternativne američke zapadne obale, Kalifornije ${ }^{10}$.

Reafirmacijom teorijskih interesa za temu svakodnevnog života s početka ovog stoljeća u fokus sve više dolaze distinktivne kategorije i koncepti. Primjerice teza da je u brojnim teoretizacijama svakodnevnog života neopravdano zanemarivan i obezvrjeđivan koncept običnog, uobičajenog, a kojemu je moguće pristupiti uspostavljanjem jasne distinkcije između kategorija „svakodnevni život“ i „svijet života“, koje su se, približavanjima filozofijske fenomenologije i sociologije, nerijetko tretirale u liniji kontinuiteta i suodnosne bliskosti, a ne razlika (Sandywell, 2004.).

Na kraju uvodnog dijela treba spomenuti i da je u hrvatskom jeziku moguće pronaći barem nekoliko leksičkih varijanti koje se nerijetko preklapaju kada je riječ o nosivom označitelju ovih fenomena. Standardnom i najučestalijem „svakodnevni život“, koji je i ekvivalent engleskoj verziji (everyday life), uz bok se postavljaju termini „svakodnevica“, „svakidašnjica“ i/li „svakodnevlje“. Dok se prve tri varijante češće pojavljuju u sociološkim, antropološkim i kulturalno studijskim bavljenjima ovom temom, „svakodnevlje“ se uvriježilo u filozofijskim pristupima ${ }^{11}$. U ovom se članku nećemo opteretiti takvim lingvističko-semiološkim distinkcijama te ćemo sve spomenute termine tretirati jednakopravno, odnosno koristiti ih kao potencijalne sinonime jednakih razina važenja i značenja za srodne tipove fenomena i sadržaja.

Ovaj članak kani prikazom odabranih, ali reprezentativnih, teorija svakodnevnog života artikulirati sve tri nosive razine - mikro, mezo i makro - u sociološkim, ali i u istraživanjima nekih drugih društveno-humanističkih disciplina, te propitati primjerenost uvriježenih teza o primarnosti mikroteorija nad makroteorijama svakodnevice u proučavanjima fenomena društvene zbilje. Takav problemski izazov slijedi i trag razlikovanja onih aspekata svakodnevice koji su više podložni institucionalizaciji, službenom kodiranju i strategijama vladanja od nekih drugih praksi u svakodnevici na koje želimo u članku staviti naglasak, a koje su sklonije zagovaranju otpora, odnosno koje osiguravaju temelje za društvene pokrete opozicijskog tipa djelovanja (Burkitt, 2004.).

\footnotetext{
10 Jedna od najvažnijih grana mikrosocioloških istraživanja svakodnevnog života - etnometodologija, razvija se na Sveučilištu Kalifornija u Los Angelesu od sredine 1950-ih godina, a značajniji su doprinosi u tom polju napravljeni i na drugim poznatim kalifornijskim sveučilištima poput Berkeleya u predgrađu San Francisca ili Sveučilište San Diego.

11 Tako na primjer Željko Pavić, u jednom od rijetkih članaka na ovu temu napisanih na hrvatskom jeziku, a prilikom filozofijskog razmatranja „refleksivne sociologije“ u kontekstu odnosa fenomenologije i sociologije, gotovo isključivo koristi termin „svakodnevlje“ te nudi prikaz različitih perspektiva i razumijevanja tog pojma, od Webera, preko Lukácsa i Heller, prema Husserlu i Schűtzu (vidi u Pavić, 1994.:282-286).
} 


\section{Teorije svakodnevnog života u mikrosociološkoj perspektivi}

Premda mikroteorijske perspektive svakodnevice neće biti u središtu ovog rada, neke teze i autori pod okriljem takvih pristupa trebaju biti spomenuti barem u osnovnim natuknicama. Prije svih riječ je o nalazima Harolda Garfinkela u okviru američke etnometodologije, potom uvidima pripadnika tzv. njemačkog sociološkog formalizma Georga Simmela te istraživanjima Ervinga Goffmana u okviru tzv. simboličkog interakcionizma čikaške škole sociologije. Također, opće je mjesto da su se središnji tokovi razvoja sociologije svakodnevnog života upravo bazirali na konstantnom etabliranju spomenutih mikrosocioloških teorija, između ostalog i putem kritike makrosociologije. Ta je kritika bila sveobuhvatna, zahvatila je kako pozitivizam na jednoj tako i kritičke teorije društva na drugoj strani. I jednima i drugima - bez obzira na ogromne razlike koje ih karakteriziraju i čine njihovo svođenje pod zajednički nazivnik gotovo nemogućim - pripisan je zajednički krimen: navodno jednodimenzionalan i determinirajući pogled na heterogenu i kompleksnu društvenu zbilju svakodnevnog života. Središnje mjesto te kritike bio je tretman pojedinačnog aktera društvenog života, bilo da se radilo o ideji pasivnog aktera kao tabula rasa figuri koja naprosto mimo svoje volje internalizira društvene norme i vrijednosti ili o ograničenjima homo economicusa, čovjeka čije su društvene, političke ili ideološke karakteristike puki rezultat njegove ili njene klasne pripadnosti (Adler i sur., 1987.:218).

Povijesno-kontekstualno interpretirano, Harold Garfinkel i ostali etnometodolozi započinju svoja istraživanja svakodnevnog života poprilično žestokom kritikom dominantnih socioloških sistemskih teorija s kraja 1950 -ih i s početka 1960 -ih ${ }^{12}$ godina, koje se mogu dovesti i u vezu s već spomenutim kontrakulturnim i alternativno-životnim trendovima tog vremena, naročito u Kaliforniji. Jedna takva povezujuća varijabla između ishodišta etnometodologije i pripadajućih joj društveno-povijesnih obilježja epohe promjena je u percepciji statusa klasično shvaćenog autoriteta, u ovom kontekstu je to figura „profesionalnog sociologa“, koji iz etnometodološke perspektive postaje tek jedan od članova društva ${ }^{13}$ zainteresiran za opise društvenog svijeta, a ne znalac ili ekspert oboružan znanjima, čijim se interpretacijama zbog toga dodjeljuje posebno, povlašteno mjesto. Garfinkelovim riječima, njegov se rad bavi „opisima društva koje njegovi članovi, uključujući i profesionalne sociologe, koriste i tretiraju kao uzajamno poznate, te ih zajedno uzimaju zdravo za gotovo kao uvjet svojih provedivih prava da bez posredovanja - tj. kao uvjet svoje 'kompetentnosti' - upravljaju i razmjenjuju odluke o znanju, činjeničnosti, metodi i uzročnom tkanju" (Garfinkel,

12 Prvenstveno je ta kritika usmjerena na funkcionalizam Talcotta Parsonsa, ali i na niz drugih dominantnih normativnih makrosocioloških teorija s početka druge polovice 20. stoljeća, kakve su, na primjer, dokumentarna metoda Karla Mannheima ili latentne strukture stavova Paula Lazarsfelda.

13 Jedna od simboličkih etnometodoloških gesti u kritici „tradicionalne“ sociologije jest i doktrinarno inzistiranje na otklonu od uvriježene terminologije u disciplini, stoga su uobičajeni „društveni akteri“ za etnometodologe „članovi društva“. 
2006.:61). Na takvim pretpostavkama Garfinkel gradi platformu za svoje temeljne istraživačke interese, a oni se tiču svakodnevno životnih procesa, okolnosti i uvjeta za „proizvodnju činjenica o zajedničkoj kulturi“ te konstrukciju „zdravorazumskog znanja o socijalnim strukturama“. Neki pak autori upravo na primjeru etnometodologije nalaze elemente za nadilaženja dihotomija poput mikro/makro, dio/cjelina ili individua/društvo, tvrdeći da su etnometodologija i društvene sistemske teorije u kompleksnom dijalektičkom procesu, odnosno da zbog visoke razine apstrakcije sistemskih teorija etnometodologija može biti shvaćena i analizirana kao praktična logika sistemske teorije (Yu-Cheng, 2012.).

Ako ćemo slijediti trag povijesne kronologije, onda je nesumnjivo prvi „mikrosocio-

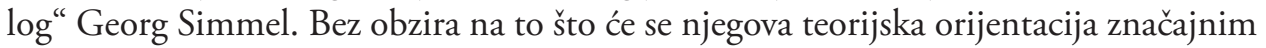
dijelom kretati u okvirima nasljeđa koje se u međuvremenu etabliralo kao „veberijanska“ tradicija u sociologiji, nasuprot „dirkemijanskoj“ - odnosno na pretpostavci o ontološkom primatu akterovog, čovjekovog subjektivnog djelovanja u usporedbi s tezama o dominaciji postojećih sistemskih društvenih struktura - upravo će Simmel u svojim esejima kao prvi ponuditi analizu „malih“, ali pokazat će se itekako važnih i indikativnih, aspekata svakodnevnog modernog života. Ostat će tako iza njega prava riznica razrade sićušnih fenomena svakodnevice: motivi mode, obroka, nakita, stranca i flâneura ${ }^{14}$, društvenih interakcija... Takve elemente i momente Simmel naziva „društvenim ćelijama“, smatrajući da životni proces revitalizira sam sebe upravo preko njih, interakcijom između društvenih ćelija, njihovim međusobnim utjecajima, slaganjima i neslaganjima, suradnjom ili konfliktom. „Društvene ćelije“ i tipovi njihovih interakcija fundamentalna su podloga svakodnevnog života, a svakodnevica je, prema Simmelu, akumulacija takvih momenata. Ne postoji niti jedan fragment svakodnevice koji bi bio u potpunosti isključen, koji ne bi bio povezan s nekim drugim fragmentima, društvenim ćelijama svakodnevnog života (Highmore, 2002.:38).

U takvom viđenju i opisu svakodnevnog života dolazi do izražaja još jedan snažan utjecaj iz razdoblja vrlo rane sociologije, koji nije zaobišao ni Simmela, a to je onaj Herberta Spencera i njegovih poznatih biološko-organicističkih razumijevanja i tumačenja društva. Naročito je to istaknuto u Simmelovoj, na momente više psihološkoj nego sociološkoj, deskripciji motiva koji kod njega zauzima posebno važno mjesto, a to je velegrad, njegovi stanovnici i značajke urbanog duhovnog života. Tako piše da „psihološka osnova na kojoj se javlja tip velegradskih individualnosti je intenziviranje živčanog života koje proizlazi iz brzih i neprekidnih izmjena vanjskih i unutarnjih dojmova“, potom da „tip stanovnika velegrada [...] sebi stvara organ kojim se štiti od iskorijenjenosti“, a to je „razum, racionalnost“ te kako je „intelektualistički karakter

\footnotetext{
${ }^{14}$ Vjeran Katunarić, u predgovoru jedine kod nas do sada objavljene knjige koja predstavlja sistematično napravljenu kolekciju izabranih Simmelovih tekstova (Kontrapunkti kulture, Jesenski i Turk, Zagreb, prvo izdanje 2001., a drugo 2014.), taj poznati Baudelairov motiv-figuru prevodi kao „lunjalo“ (Katunarić, 2014.:7).
} 
velegradskog duševnog života“ suprotnost „onom u malom gradu koji je više orijentiran na srce i osjećajne odnose“ (Simmel, 2014.:140-141).

No Simmel nam je na ovom mjestu zanimljiv i važan još iz jednog razloga, a to je činjenica da je u svoje vrijeme imao snažan utjecaj na tada mlade studente iz SAD-a, Albiona W. Smalla i Roberta E. Parka, koji će nešto kasnije postati prominentne figure među utemeljiteljima tzv. čikaške škole sociologije, a pohađali su Simmelova predavanja u Berlinu krajem 19. stoljeća. To ukazuje na posredujuću vezu između Simmelovih opisanih teza i onog što će u povijesti sociologije postati poznato kao tradicija simboličkog interakcionizma, s Ervingom Goffmanom kao najznačajnijim autorom u kontekstu središnje teme ovog članka.

Goffman, kao središnja autorska figura suvremenog simboličkog interakcionizma, dao je velik doprinos proučavanjima svakodnevnog života. Iz njegovog bogatog analitičkog i konceptualnog opusa, a konkretno povezano s našom temom, naročito nam je zanimljiva i važna Goffmanova poznata „dramaturška analiza“, razrađena u knjizi Predstavljanje sebe u svakodnevnom životu (The Presentation of Self in Everyday Life, 1959.). Putem metafore o svakodnevnom životu kao teatarskoj pozornici na kojoj kao pojedinci „igramo društvene uloge“, „ritualno i ceremonijalno“ kreiramo određene tipove socijalnih interakcija, autor izvodi teze o „prednjem i stražnjem planu u našem svakodnevno životnom prezentiranja sebstva“. Pritom je „prednji plan“ upravo pozornica svakodnevnog života na kojoj „igramo uloge“, a da toga nismo nužno ni svjesni, to jest kreiramo različite tipove društvenih interakcija (gradimo saveze, prijateljske odnose ili poslovne koalicije, ulazimo u konflikte, antagonizme i sukobe...), dok je „stražnji plan“ rezerviran za intimnu, osobnu stranu naših života.

Oba teorijska pristupa spomenuta u ovom poglavlju, etnometodologija i simbolički interakcionizam, u literaturi na teme suvremene sociologije i svakodnevnog života podvode se pod zajednički nazivnik - američka mikrosociologija, koja je u bitnome određena tipično američkom društvenom i kulturalnom tradicijom radikalnog individualizma. Tu se negdje baštine i elementi kritike koja im se nerijetko upućuje po pitanju pristupa koje preferiraju u analizi fenomena kojima se bave: da se radi o „kulturnom individualizmu“, koji prvenstveno tretira „društveno nestrukturiranog aktera“ izvan društvenog konteksta u koji je on uronjen i o kojemu ovisi (Spasić, 2004.:117). Znajući da društveno-kulturne i ekonomsko-političke okolnosti ipak značajno, ako ne i presudno, oblikuju naše bivanje i djelovanje u svijetu, u nastavku članka posvetit ćemo se onim teorijama svakodnevnog života koje stavljaju naglasak upravo na takve aspekte naših individualnih i kolektivnih egzistencija. 


\section{3. "Ukliještena" svakodnevica: mezorazina}

Iako najmanje zastupljena perspektiva u teorijama svakodnevnog života, mezorazinu nalazimo kao važnu premosnicu između mikro i makroproučavanja ovih fenomena. Razlozi za to su i širi disciplinarno-sociološki. Naime, od 1960-ih godina nadalje, dakle u razdoblju koje smo definirali kao ključno za postuliranje teorijsko-istraživačkih interesa na temu svakodnevnog života, događa se važan epistemološki obrat u sociologiji. Narušava se do tada prešutno važeća disciplinarna binarnost, uvid da su gotovo sve sociološke teorije vezane uz neku od dviju spomenutih temeljnih metateorijskih socioloških paradigmi. $\mathrm{Na}$ jednoj je strani tzv. „weberijanska“, po kojoj društveni svijet nastaje tek kroz neprestanu kreativnu, interpretativnu aktivnost pojedinaca u procesu komuniciranja, pa se u taj kontekst ubrajaju i spomenute mikrosociologije svakodnevice (simbolički interakcionizam, etnometodologija i fenomenološka sociologija, a uz njih i teorija racionalnog izbora), a na drugome je polu tzv. „dirkemijanska" paradigma, prema kojoj je društvo na neki način objektivna činjenica, razvija se i djeluje prema više ili manje već određenim zakonitostima, što znači da se na konkretne motive i ponašanja pojedinaca ne treba previše osvrtati. Najvažnije teorije takve sociološke tradicije su funkcionalizam, konfliktna teorija, strukturalizam te neke verzije marksizma, poput Althusserove.

Spomenuta promjena perspektive sastoji se u artikulaciji pristupa koji su zagovarali integralnije oblikovanje teorija, takvo koje bi dosljednije uzimalo u obzir oba pola društvene realnosti, kako mikro tako i makro socijalnu razinu, odnosno kako načelo subjektivne kreativnosti djelujućih aktera u njihovim svakidašnjim rutinama tako i esencijalne karakteristike objektivnih društvenih struktura u smislu datosti, na koju kao pojedinci nemamo prevelikog utjecaja (Stankovič, 1999.:231). Upravo se u takve „integrativne“ pristupe ubrajaju i oni koji su nam u ovom tekstu važni kao mezorazina teorijskih elaboracija svakodnevice. To su socijalni konstruktivizam Bergera i Luckmanna te neki aspekti Bourdieuove - iskoristimo jednu od brojnih sintagmi kojima se označava njegov rad - ,sociologije društvenih praksi“.

Neosporno je da se Bergerova i Luckmannova „socijalna konstrukcija zbilje“ tijekom proteklih desetljeća (knjiga je prvi put objavljena 1966. godine) etablirala kao kanonsko djelo „integrativnih teorija“ u sociologiji. S obzirom na to da je jedan od glavnih motiva njihove studije pitanje „kako čovjek može znati“, knjiga je u međuvremenu postala i nezaobilazna referenca za sociologiju znanja. Pritom autori naglasak stavljaju na tip znanja s kojim smo se već susreli kod Garfinkela, a to je zdravorazumsko znanje, koje ih zanima više od „znanja ideja“. Pitanje je odakle se baštine znanja u svakodnevnom životu, koji su temelji tih i takvih znanja (Hromadžić i Popović, 2019.:36). Berger i Luckmann se u knjizi najviše približavaju motivu svakodnevnog života na mjestu na kojem priznaju da zaokret u redefiniranju sociologije znanja koji su napravili prvenstveno duguju Alfredu Schützu, koji se, kako navode, „koncentrirao na strukturu zdravorazumskog svijeta svakodnevnog života" (Berger i Luckmann, 1992.:30). 
Mnogi su primijetili važnost veze između sociologije znanja, zdravorazumskog svijeta života i svakodnevice u radu Bergera i Luckmanna. Dušan Marinković tako uvodi sintagmu „epistemološka skromnost“ te njome želi označiti gestu kojom ta dva autora uklanjaju dotadašnje barijere po pitanju poimanja ljudskog znanja i uvriježenih hijerarhija u klasifikaciji znanja, pri čemu se u središte svakodnevice postavlja zdravorazumsko znanje: „povratkom svakodnevici kao vrhunskoj društvenoj stvarnosti uklonjena je prepreka koja je dugo vremena sociologiju znanja ograničavala na posebna, izdvojena i specijalizovana znanja" (Marinković, 2019.:46). Marina Simić nudi antropološko čitanje Bergerove i Luckmannove ostavštine na način povezivanja teorije etnografije i teorije socijalnog konstruktivizma. Pritom kreće od kategorija prostora i vremena ka konceptu prostora-vremena svakodnevice i predlaže da se uloga sjećanja (u funkciji vremena) u kontekstu analize neke epohe (autorica se bavi razdobljem tzv. postsocijalizma u Europi) sagleda posredstvom analize svakodnevnih praksi, umjesto uobičajenog fokusa na narative (Simić, 2019.).

Što se pak tiče druge teorijske tradicije koju ovdje tretiramo kao relevantnu za mezorazinu sociologije svakodnevnog života, a to je Bourdieuova, postoje teze da je u njegovom radu „svakodnevica svojevrsna sinteza čitavog predmeta sociologije, budući da je on shvata i u njenom aspektu iz dana u dan` (prakse koje se ponavljaju) i u aspektu ‘dan za danom» (ukupan zbir pojedinčevih iskustava)“ (Jacyno u Spasić, 2004.:286). Međutim, tema svakodnevnog života kod Bourdieua nije eksplicitno elaborirana. Naime, za njom valja tragati kao implicitno prisutnom u gustom tkanju Bourdieuove teorije. Na primjer, slijedeći liniju njegovog razumijevanja binarnog koncepta objektivizam - subjektivizam, koji se naslanja na ranije spomenutu klasičnu sociološku dihotomiju struktura - djelovanje/agencija, pri čemu Bourdieu pledira na važnost nadilaženja ograničenja koja se nalaze u pristupima koji pokazuju sklonost ka interpretacijama društvenog svijeta isključivo kroz jednu ili drugu perspektivu. Na tome gradi svoju čuvenu teorijsku trijadu, koja je ujedno i Bourdieuov odgovor na limite prethodne dihotomije, a to je polje (ekvivalent strukturi) - habitus - praksa (ekvivalent djelovanju $)^{15}$; u kojoj je povezujući član koncept habitus, integrativni faktor koji uključuje ukupnost akterovih, kako već stečenih tako i dispozicija koje se stječu na individualnoj i društvenoj razini (više u Bourdieu, 2002.:89-111).

Još istančanija čitanja vodit će nas u pravcu Bourdieuvih distinkcija, velikog autorskog konceptualnog pojma - označitelja, koji otvara perspektivu za druge važne kategorije:

${ }^{15} \mathrm{Na}$ ovom se mjestu otvara prostor i za uvođenje dijela Foucaultove teorije koja ima dodirnih točaka s Bourdieuom i njegovom tročlanom koncepcijom, polje - habitus - praksa. Riječ je o Foucaultovoj teoriji moći i uvjetima njenog proizvođenja te s time povezanoj konceptualizaciji teorije subjekta. Konkretno, radi se o tezi da je decentraliziran i fragmentiran subjekt mjesto preko kojega je moguće pratiti kreiranje svakodnevice. No daljnje slijeđenje dihotomije koja određuje ovu tezu: subjekt u smislu aktivnog značenja (onaj koji vrši radnju, to jest akter zbivanja) vs. subjekt u stanju podređenosti, vodila bi nas izvan zadanih okvira ovog rada. 
tipove kapitala (socijalni, ekonomski, kulturni i simbolički), klasnu raslojenost društva i klasne putanje, društveni prostor, ukus... ${ }^{16}$ No nama je Bourdieu u članku prvenstveno zanimljiv i bitan autor u kontekstu njegove prepoznatljivo angažirane geste: opetovanog naglašavanja važnosti društvenih uvjeta egzistencije u kojima se pojedinci i socijalne skupine razvijaju te apela da se svijetu pristupa djelatno, aktivno. ${ }^{17}$ Time nam pomaže raskrčiti put kojim se pokušavamo kretati u prikazu teorija svakodnevnog života na ovome mjestu, a to je iskorak iz mikrosocioloških teorija s naglaskom na pojedinačnoj individui, preko zaobilaženja teza koje glorificiraju postmodernističko-idolatrijsku perspektivu svakodnevice, to jest stavljaju prioritet na ideje o igrivom, slobodnom i kreativnom građenju identiteta koje nije socijalno-klasno uvjetovano ${ }^{18}$, prema naglašavanju važnosti strukturnih pitanja dinamike društvenih moći, borbe hegemonija i ideologija te njihovih artikulacija u svakodnevnom životu.

\section{Makroteorije svakodnevnog života: kritika, otpor, revolucija}

Jedna od centralnih figura makroteorijskih promišljanja svakodnevice zasigurno je francuski filozof Henry Lefebvre. Nije pretjerana tvrdnja da u bogatom opusu tog neomarksistički orijentiranog autora, na čiju su intelektualnu orijentaciju presudno utjecali Hegel, Marx i Nietzsche, tema svakodnevnog života zauzima središnje mjesto. Simbolički je to obilježeno i činjenicom da je na jednom od općenito najvažnijih filozofskih i socioloških teorijskih uradaka o svakodnevlju, trotomnoj Kritici svakidašnjeg života, Lefebvre radio puna tri i pol desetljeća. ${ }^{19}$ Osim te opsežne studije, Lefebvre u

16 Ključna Bourdieuova djela u kojima podrobno raščlanjuje ove motive nastaju na prijelazu iz 1970-ih u 1980-e. To su La Distinction. Critique Social du Jugement (Distinkcija. Društvena kritika suđenja) iz 1979. i La Sans Pratique (Praktični osjećaj) iz 1980. godine.

17 Iako društveno-politički angažiran intelektualac tijekom gotovo cijele svoje karijere, Bourdieu je zadnjih $7-8$ godina života i rada gotovo isključivo posvetio aktivizmu. Tako je 1995. godine osnovao i pokrenuo društveni pokret „Razlozi za djelovanje“ (Raisons d'agir). Radilo se o inicijativi baziranoj na četirima osnovnim razinama: obrana i promocija autonomije svakog tipa kulturnih djelatnika; nakladnička djelatnost, s naglaskom na kraćim, široj populaciji dostupnim esejima o gorućim socijalnim pitanjima; društveno-znanstvena istraživanja ekonomsko-socijalnih posljedica neoliberalnih politika i oblikovanje nove internacionale (više u Štrajn, 2002.:252-253).

18

8 Prostorna nam ograničenja ne dopuštaju da se posvetimo i prikazu nekih tipično postmodernih teorija svakodnevnog života koje se pojavljuju u zadnja dva, dva i pol desetljeća 20. stoljeća. Među njima se ističe francuska postmodernistička tradicija, autori poput Michela de Certeaua (na hrvatski je jezik je 2003. godine prevedena njegova najpoznatija knjiga Invencije svakodnevice, na francuskom prvi put objavljena 1980.) i Michela Maffesolija.

19 Prvi tom knjige Kritika svakidašnjeg života, s podnaslovom Arka (L'Arche), objavljen je 1947., drugi dio koji je podnaslovljen Temelji sociologije svakodnevnog života (Fondements d'une sociologie de la quotidienneté) 1961., a posljednji, treći dio imenovan Kritika svakodnevnog života, III. Od moderne do modernizma (Za metafilozofiju svakodnevnog života) ((Critique de la vie quotidienne, III. De la modernité au modernisme (Pour une métaphilosophie du quotidien)) izašao je 1981. godine. 
međuvremenu piše još jednu knjigu koja je eksplicitno posvećena ovoj temi, a prvi je put objavljena povijesne 1968., važne godine u europskoj i svjetskoj povijesti ${ }^{20}$. Radi se o knjizi Svakidašnji život u modernom svijetu (La vie quotidienne dans le monde moderne). ${ }^{21}$

Opće je mjesto da su Lefebvreove interpretacije svakodnevnog života iz desetljeća u desetljeće poprimale sve tmurnije i pesimističnije tonove. Takvu tendenciju moguće je prepoznati u intervalu dugom dvadesetak godina, od objavljivanja prvog, preko drugog dijela Kritike pa do knjige Svakidašnji život u modernom svijetu. Naime, početni entuzijazam i optimizam, zasigurno kontekstualno određeni i završetkom Drugog svjetskog rata te pobjedom nad nacifašizmom, postupno ali prepoznatljivo biva transformiran, nadomješten autorovim uvidima i analizama o rekuperacijskoj moći i snazi neokapitalističkog sustava liberalne demokracije da praksama komodifikacije, reifikacije i kooptacije duboko odredi karakter i trendove svakodnevno životne zbilje modernog svijeta, s posljedicama u vidu otuđenja, rutinizacije, dokoličarskih potrošačkih praksi... Lefebvreovim riječima: „U toku razmatranog razdoblja (1946 - 1961) svakidašnjica se izmijenila, ne u pravcu širenja svoga latentnog bogatstva, već u obrnutom pravcu: osiromašenje, manipulacija, pasivnost. Kapitalizam u tom razdoblju osvaja nove sektore: poljoprivredu, ranije većim dijelom pretkapitalističku - povijesni grad koji se raspršuje eksplozijom i implozijom - cijeli prostor što ga osvaja turizam i dokolica, naposljetku kulturu, tj. civilizaciju svedenu na razvoj industrijom kulture i podređenu njoj - konačno i osobito svakodnevicu“ (Lefebvre, 1988.:516). U nastav-

20

1968. se i danas nerijetko tretira kao "godina posljednjeg revolucionarnog pokreta" na Zapadu, a s obzirom na činjenicu da su u središtu pokreta bili studenti, kojima će se potom priključiti radnici iz brojnih industrija, 1968. je postala i sinonim generacijskog bunta i otpora autoritetima. Premda Lefebvre nije bio jedan od intelektualnih zaštitnih znakova 1968. iz „prvoga reda“, kao što su to bili primjerice Sartre ili Foucault, njegova uključenost u ta društveno-politička zbivanja koja su bila politički lijevo orijentirana - tražile su se pravednije ekonomsko-socijalne i klasne politike te više „socijalne države blagostanja“, a manje pogodovanja „državi kapitala“ - nije upitna. Po jednoj je strani to razvidno preko snažnih utjecaja koje je kao profesor imao na oblikovanje stavova Deborda i Vaneigema, središnjih protagonista Situacionističke Internacionale, koja je bila važan dio tzv. „okupacijskog odbora“ na pariškom sveučilištu Sorbonne, epicentru pokreta i pobune. Također, neki Lefebvreovi teorijski koncepti i motivi naići će na široku prihvaćenost prilikom pokušaja da se objasne i razumiju zbivanja u svibnju i lipnju 1968. godine. Primjeri su toga karnevalska urbana svetkovina u kojoj klijaju zameci revolucionarnog obrata (koncept la fête) ili „trenuci“ (moments), svojevrsne točke prijeloma s monotonom i repetetivnom svakodnevnom zbiljom, momenti intenzivnog iskustva svakodnevice (gađenje, šok, oduševljenje...), koji u sebi nose zametak društvene promjene, otvaraju kritiku formaliziranih i otuđujućih radno-životnih praksi u kapitalizmu.

${ }^{21}$ Dok je Kritika svakidašnjeg života u većoj mjeri obilježena hegelijansko-marksističkim razumijevanjem i tumačenjem svakodnevice, stoga se i govori o „dijalektici svakodnevnog života Henryja Lefebvrea“, Svakidašnji život u modernom svijetu više je u znaku Nietzschea. Razvidno je to preko aplikacije tipično Nietzscheovih motiva vječnog vraćanja istog, beskonačnosti, pojavljivanja... u kontekstu Lefebvreovog nastojanja da svakodnevni život prikaže kao nedovršen, difuzan, satkan od stalnih pojavljivanja, obilježen repetitivnošću, rekapitulacijama i nostalgičnim reminiscencijama života (Lefebvre, 1971.). 
ku te misli iznosi i tezu koja se na neki način referira na već prethodno spomenuto u članku, a vezano uz antropološka istraživanja svakodnevice (bilješka br. 6 u ovom članku), to jest „veliki obrat" u toj disciplini započet u 1960-im i 1970-im godinama: „svakidašnjica nadomještava kolonije. Nesposobni da zadrže stari imperijalizam, tražeći nove instrumente dominacije [...] kapitalistički rukovodioci tretiraju svakidašnjicu kao što su nekad tretirali kolonizirane teritorije: goleme tezge (samoposluživanja i trgovački centri) - apsolutno prevladavanje razmjene nad upotrebom - dvostruko iskorištavanje onih kojima se vlada kao proizvođačâ i kao potrošačâ" (ibid.). Tim aspektima svakodnevice Lefebvre će posvetiti dobar dio svoje kritike u kontekstu analize konzumerističkih trendova u drugoj polovici 20. stoljeća.

Kao hegelijansko-marksistički materijalist, Lefebvre vidi svakodnevni život kao poprište dijalektičkog susreta s društvenim i prirodnim svijetom. Na jednom mjestu, u studiji koja nije eksplicitno posvećena ovoj temi, Lefebvre povezuje motiv svakidašnjeg s Marxovom ostavštinom. Titulirajući svakidašnje kao bazu društva, kao tvorevinu koja je središnja u društvenoj teoriji, Lefebvre tvrdi da premda Marx nije prepoznao svakidašnje kao takvo, izveo ga na razinu konceptualnog pojma, ideja svakidašnjeg ,je smisao njegove zamisli koja nije bila ograničena na političko i ekonomsko" (Lefebvre, 1981.:153). Prema interpretaciji Muhamedina Kullashija, jedan od Lefebvreovih ishodišnih problema kada je riječ o kritici svakidašnjeg života jest pitanje usmjereno na održavanje stvarnosti svakidašnjice, njezinu stabilnost, njeno neprestano reproduciranje u jednoličnosti, tvrdokornosti, „prirodnosti“ (Kullashi, 1986.). Naime, Lefebvreova kritika svakodnevice suvremenog svijeta odvija se na dvama suodnosnim kolosijecima. Po jednoj strani to je opservacija cjeline suvremenog svijeta kao razdrtog totaliteta sazdanog od države, kulture, tehnike, institucija, etabliranih odnosa itd., a po drugoj kritika komodificiranih dokoličarskih praksi i konzumerističkog kapitalizma. Odnosno, kritika buržoasko-kapitalističkog društva, u kojemu su sve radne i životne aktivnosti izrazito diferencirane i specijalizirane, ne nudeći mogućnost da ih se konsolidira u preglednu cjelinu.

No Lefebvre doktrinarno slijedi hegelijansko poimanje totaliteta, njegovo je mišljenje da svakodnevni život jest i ,'vezivno tkivo» koje daje totalitetu njegovu strukturu i koherentnost" (Gardiner, 2000.:79). Upravo takvo razumijevanje totaliteta, te unutar njega poznatog koncepta „totalnog čovjeka“ ili „totalne osobe“, središnje je mjesto Lefebvreovog utopijsko-emancipatornog projekta. Prepoznajući taj motiv, Martin Jay nas podsjeća na Lefebvreovu ranu afilijaciju s nadrealistima i dadaistima, $s$ umjetničkim motivima društvene transgresije, naglašavajući pritom da je Lefebvre više nego drugi autori srodne kritičke orijentacije isticao otvorenost totaliteta spram budućnosti, kao i njegovu dinamičnost (Highmore, 2002.:118). Rade Kalanj takvo Lefebvreovo poimanje otvorenog društvenog totaliteta i njegovih procesa karakterizira kao dijalektičku metodu u sociologiji kojoj je strana svaka linearnost i zatvorena jednoznačnost (Kalanj, 1988.). 
Premda je svakodnevni društveni život otuđen diktaturom kapitalizma i buržoaskom ideologijom - što je razvidno preko niza ekonomsko-socijalnih fenomena i manifestira se u brojnosti komercijalnih dokoličarskih praksi, bujanju konzumerizma, tehnokratskoj instrumentalnosti života, općenito jačanju onog što se lefebvreovski može nazvati porašću „privatizacijske svijesti“ - Lefebvre u ranoj i srednjoj fazi svoga rada zaziva utopijska načela ljudske dealijenacije. Klasično mjesto tog tipa u njegovom radu jest spomenuti projekt „totalnog čovjeka“22, koji „sugerira univerzalnu subjektivnost, nejasno prizivanje 'istinske’ prirode čovječanstva“ (Highmore, 2002.:127). Lefebvreov „totalni čovjek“ jest utopijska figura realizirane osobnosti, čovjek oslobođen nametnutih okova kapitalističko-buržoaske ideologije, koji ostvaruje svoje potencijale, kreativnost i maštovitost, ispoljava svoju sklonost ka ludičkom i dionizijskom, a mjesto njegove realizacije jest metaforički shvaćen motiv festivala ili karnevala, odnosno moment životne rekonfiguracije, artikulacije opozicijske kulture, eksplozije potlačenog i potisnutog kroz svakodnevicu. ${ }^{23}$

Složit ćemo se s Gardinerom, koji u svome čitanju Lefebvrea nudi zaključak da ga, usprkos nerijetko pesimističnom tonu, treba razumjeti kao arhetipskog revolucionarnog optimista. Takav optimizam moguće je prepoznati u njegovim stavovima o potencijalima ljudskog duha i tijela, radikalnom subjektivitetu u konačnici nesvodivom na kapitalističku instrumentaliziranu birokratsku logiku, u oslobađajućim snagama erosa, popularnim svetkovinama i karnevalima urbanih prostora, dijalektičkom umu (Gardiner, 2000.:99). Stoga je sasvim razumljivo da je predstavljao nadahnuće i inspiraciju „šezdesetosmašima“, a posebice tzv. situacionistima među njima.

Članovi Situacionističke internacionale, važni protagonisti kratko spomenutih zbivanja «68. u Francuskoj i Europi, dijelili su s Lefebvreom intelektualni, teorijski i umjetnički senzibilitet, svojevrstan amalgam hegelijanizma, marksizma i nadrealizma. U fokusu njihove angažirane kritike bile su socijalno-ekonomske posljedice kasnoga kapitalizma i suvremenog konzumerizma, prije svega opća društvena pasivizacija i posljedično otuđenje u društvenoj svakodnevici. Stoga je i njihov apel, poziv na revoluciju u slogu radikalne ljevice, nužno uključivao i marginalne, ali važne aspekte svakod-

$\mathbf{2 2}$ Lefebvre motiv „totalnog čovjeka“ prvi put razrađuje u svojoj knjizi Dijalektički materijalizam iz 1940. godine. Taj koncept, kao i ostali iz njegove revolucionarno-utopijske faze rada, simptomatično izostaje u razdoblju „kasnog Lefebvrea“ u 1970-im i 1980-im. Tada ga započinju preokupirati problemi poput društvene produkcije prostora, popularizirani od nekih njegovih učenika poput Davida Harveya te obilato artikulirani u akademskim domenama sociologije grada ili antropologije urbanog.

23 Naravno, razumijevanje i interpretiranje kasnosrednjevjekovnog motiva karnevala i karnevalskog kao revolucionarnog simbola pučkog otpora i pobune, potencijalne točke prevrata i promjene u svakodnevici, nije Lefebvreova posebnost. Vjerojatno je najpoznatija referenca na tu temu poznata Bahtinova studija o Rabelaisu iz 1965. godine (iako dovršena još 1940.). Lefebvre svoju knjigu o tom istom, čuvenom francuskom renesansnom književniku, liječniku i svećeniku objavljuje 1955., a srodnu liniju tumačenja karnevala slijede i brojni drugi autori, na primjer Bataille ili Yves-Marie Bercé. 
nevnog života, nerijetko zaboravljene i prešućene u velikim ideološkim narativima. Kako je to ponešto poetski definirao Raoul Vaneigem, uz Deborda najprominentniji situacionist, poznat po konceptu imenovanom „survivalizam“24: „Svatko tko govori o revoluciji i klasnoj borbi, ne da bi se eksplicitno odredio ka svakodnevnom životu - ne razumijevajući što je subverzivno u ljubavi i pozitivno u odbacivanju ograničenja - izgovara mrtve riječi“ (Vaneigem, 2012.:11).

Kada je pak riječ o Debordu, njegove teze o svakodnevnom životu sastavni su dio autorovog ključnog teorijskog motiva, a to je koncept spektakla, ujedno i središnje problemsko mjesto cjelokupnog situacionizma, simptom iz same srži ideologije konzumerističkog kapitalizma. U svome poznatom Društvu spektakla Debord motiv svakodnevnog života smješta u kontekst šireg pitanja „spektakularnog vremena“, kojemu posvećuje cijelo poglavlje knjige, a u užem smislu svakodnevni život tretira kao nerazdvojivo povezan s tzv. pseudocikličnim vremenom. Odgovore na pitanja što je to pseudociklično vrijeme i u kakvoj je ono vezi sa svakodnevnim životom u kapitalističko-konzumerističkoj epohi spektakla druge polovice 20. stoljeća Debord nudi u paragrafima 148. - 150.: „potrošno vreme koje proističe iz modernog oblika proizvodnje i koje se vraća u svakodnevni život društva kao pseudociklično vreme“; uloga pseudocikličnog vremena je „da uspori konkretan svakodnevni život i da održava njegovo zaostajanje“; s obzirom na to da je pseudociklično vrijeme i vrijeme potrošnje, svojstveno mu je „uvećano preživljavanje u kojem je svakodnevno iskustvo lišeno odlučivanja“ (Debord, 2006.:42). No posebice zanimljivim i inspirativnim mjestom u knjizi po pitanju svakodnevnog života nalazimo paragraf 217., u kojemu Debord, pišući o ekonomskoj materijalizaciji ekonomije i društvu koje je postalo ono što je ideologija već bila, kaže: „potiskivanje prakse i antidijalektička lažna svest koja nastaje usled tog potiskivanja, ispunjavaju svaki trenutak svakodnevnog života podređenog spektaklu“" (Debord, 2006.:56).

Utopijsko-teorijska i avangardističko-umjetnička angažirana gesta revolucionarne promjene trebala bi, u viziji situacionista, preko kritike konzumerističko-kapitalističke svakodnevice suvremenog svijeta ponuditi principe i modele novog tipa umjetnosti temeljene na ludičkoj rekreaciji ljudskih kreativnih potencijala i potpunoj participaciji. Takav svakodnevni život bio bi življen na način stalne inkluzivne umjetnosti, u kojoj bi svatko permanentno postajao umjetnikom. Uobičajenu performativnu figuru umjetnika, klasični umjetnički artefakt ili čin te konzervativnu galerijsku ili muzejsku umjetnost, nadomjestila bi slobodna, kreativna teorijsko-praktična i afirmativno-artistička kreacija vlastitih, osobnih i kolektivnih, svakodnevno životnih situacija (otud i naziv „situacionisti“), što bi bio put ka istinski participativnoj, ne-medijatiziranoj demokraciji.

24 „Survivalizam“ bi se mogao prevesti kao „ideologija preživljavanja“, život sveden na njegovu ekonomsku bazičnost, neophodnu za reprodukciju kapitalističko-konzumerističkog sustava. Rečeno Vaneigemovim stilom: raditi da bi se preživjelo, preživjeti konzumirajući, preživjeti da bi se konzumiralo i pakleni krug je zatvoren (više u Vaneigem, 2012.:137-142). 
Upravo je motiv utopije, inače nerijetko prisutan u (neo)marksističkim filozofijskim razmatranjima svakodnevlja, moguća ulazna točka ka kratkom prikazu zadnje u ovom članku izabrane makroteorijske perspektive svakodnevice, a možemo je nazvati društvenom ontologijom Agnes Heller. Iako su razmišljanja i teze Heller o „imanentnoj utopiji“, koja ustrajno egzistira u društvenom svijetu svakodnevnog života, svakako zanimljiva i vrijedna pažnje - koncipirala ih je na raskrižju kako odbacivanja ideja utopijskog socijalizma tako i kritika klasično marksističkih poimanja utopije, ali i postmodernističkog ciničnog otklona spram utopijskih scenarija kao prevladanih modernističkih narativa (više u Gardiner, 2000.:152-155) - ona pripadaju kasnoj fazi njezina rada iz 1990-ih godina. No nama je svakako, u kontekstu teme članka, još važnija ona etapa u radu Heller koja pokriva desetljeće započeto s kraja 1960-ih i završeno s krajem 1970-ih godina. U središtu tog razdoblja svakako je njena knjiga Svakodnevni život, prvi put objavljena 1970., prevedena na engleski 1984., a 1978. godine na tadašnji srpskohrvatski, prijevod koji koristimo i na ovom mjestu. Predgovor toj knjizi napisao je čuveni marksistički filozof Georgy Lukács, profesorski autoritet koji će odigrati ključnu ulogu u intelektualnom oblikovanju Agnes Heller. U tom predgovoru Lukács elaborira tezu da se jedino preko svakodnevnog života kao neposrednog oblika ljudske rodnosti, posredujućeg momenta, mogu istinski zahvatiti odnosi između ekonomskog razvitka i individue, ekonomsko-društvenog svijeta i ljudskog života (Lukács, 1978.:11-16).

Međutim, Lukácsev utjecaj na Helleričin koncept svakodnevnog života najočitiji je u njezinoj razradi društvene ontologije svakodnevnog života preko triju bazičnih razina, kojima je u osnovici zajednička kategorija ljudske rodnosti, odnosno generičke suštine čovjeka. To su: objektivacije po sebi (posebičnost), objektivacije za sebe (zasebičnost) i objektivacije po sebi i za sebe (posebičnost i zasebičnost). Već je letimičnim pogledom i elementarnim uvidima u materiju jasno da se tu radi o analizi fenomena koja se naslanja na opća mjesta marksističke filozofije, Lukácsevu teoriju klasne svijesti ${ }^{25}$ te Marxovu i Engelsovu koncepciju klasa i klasne borbe, predstavljenu u njihovom Manifestu komunističke partije iz 1848. godine.

„Objektivacije po sebi“, ili posebičnost jest temeljna, ontološka kategorija društva, kralježnica svakodnevnog života. Heller tvrdi da je „glavna karakteristika posebičnosti društvenih entiteta pre svega činjenica da bez njih ne postoji ili društvo uopšte ili bar data društvena struktura" (Heller, 1978.:221) te razlikuje tri različita, ali jedinstvena momenta tog tipa objektivacija: oruđa i proizvodi, običajni sistem i jezik. Ovladavanje tim kategorijama, pravilima njihove upotrebe, uvjet je ljudske socijalizacije, onog što se naziva društvenim starenjem, preko posebičnosti postajemo funkcionalnim člano-

25 Naravno, riječ je o Lukácsevoj analizi iz 1923. godine (knjiga Povijest i klasna svijest), razlici između „klase po sebi“, koja ima sva društveno-ekonomska obilježja karakteristična za njeno mjesto u socijalnoj strukturi, odnosno u društvenoj podjeli rada, i ,klase za sebe“, koja usto posjeduje i aktivnu svijest o svome klasnom položaju, što je preduvjet svakog kolektivnog društvenog djelovanja (više u Lukács, 1977.). 
vima društva. Iz izrečenog je jasno da kada Heller piše o objektivacijama po sebi, ona zapravo evocira opće mjesto na temu svakodnevnog života, Schützove „zalihe znanja“ društvenih aktera. Kada je riječ o zasebičnosti, „objektivacijama za sebe“, za njih će autorica zapisati da „ne mogu funkcionisati drukčije osim jedino uz pomoć svesne ljudske intencije usmerene na njih [...] one reprezentuju ljudski razvitak ne samo objektivno, već i sa pečatom odnosne intencije“ (Heller, 1978.:225). Ona pod tu kategoriju svrstava četiri velika entiteta ljudske rodnosti: religiju, filozofiju, znanost i umjetnost. Preko njih se daje smisao ljudskom životu i postojanju, a s posebičnošću su u odnosu svojevrsnog uvjetovanog antagonizma, izrastaju iz objektivacija po sebi, ali ih ujedno i nadilaze: „uzdizanje u zasebičnost znači ujedno i distancu prema posebičnosti, a ona zahteva njeno prestrukturiranje ili bar drugo tumačenje“ (ibid.). Treća, integrativna razina nazvana „objektivacije za sebe i po sebi“ satkana je, prema Heller, od formalnih kategorija koje daju identitet određenoj društveno-političkoj, ekonomskoj i kulturalnoj zajednici u vidu njezinih institucija, pravnih odredbi, zakonskih okvira i tomu slično.

Heller je zasigurno, uz Lefebvrea, najcjelovitija i najkompleksnija autorica svakodnevnog života u kontekstu marksističkih pristupa ovoj tematici. Kako zaključuje Gardiner svoje poglavlje posvećeno ovoj autorici, ona „tvrdi da bilo koja društvena teorija koja je vođena 'interesom za emancipaciju' [...] mora biti utemeljena kroz razumijevanje svakodnevnog svijeta života" (Gardiner, 2000.:155).

\section{Zaključak}

Disciplinarna, teorijska i istraživačka različitost koja je obilježila sva protekla desetljeća društveno-humanističkog znanstvenog zanimanja za temu svakodnevnog života dobacila je barem do jedne epistemološki važne premise. Ona se reprezentira u tome da svi suvremeni pristupi u sociologiji, filozofiji, antropologiji, kulturalnim studijima... koji se bave svakodnevicom sada o njoj imaju jasno oblikovanu početnu perspektivu: rana skepsa, pa i svojevrstan zazor spram svakodnevnog života kao seta navodno banalnih i trivijalnih, postmodernističko-idolatrijskih fenomena za iole ozbiljniji znanstveni interes i proučavanja, definitivno su odbačeni. Svakidašnjica je u međuvremenu „odrasla" i postala relevantnim i referentnim istraživačkim tropom. No treba reći i da se svojevrsna potentnost entiteta „svakodnevni život" u smislu društvenih transformacija kako su ih vidjeli i imaginirali i neki u ovom članku predstavljeni autori (Lefebvre, Vaneigem, Debord, Heller, Bourdieu...) za sada naprosto nije realizirala. Naprotiv, reakcionarni trendovi u društvenoj i radnoj svakodnevici o kojima su i oni pisali, fenomeni alijenacije, komodifikacije, pasivizacije i depolitizacije u ideologiji spektakla..., ispravno locirani kao prijeporna mjesta za zamišljenu emancipaciju, u međuvremenu su poprimili još čudovišnije forme u uvjetima neoliberalnog potrošačkog kapitalizma. Takva napetost između s jedne strane potencijala u svakodnevici te retrogradnih tendencija da se oni koloniziraju i potisnu na drugoj strani dokaz su inherentno dijalektičke naravi svakodnevnog života i zalog su njegovih budućih istraživanja. 


\section{Literatura}

1. Adler, P. A.; Adler, P. and Fontana, A. (1987). Everyday Life Sociology. Annual Review of Sociology, 13: 217-235.

2. Berger, P. L. i Luckmann, T. (1992). Socijalna konstrukcija zbilje: rasprava o sociologiji znanja. Zagreb: Naprijed.

3. Birenbaum, A. and Sagarin, E. (Eds.) (1973). People in Places: Sociology of the Familiar. New York: Praeger.

4. Bourdieu, P. (2002). Praktični čut II: Praktične logike. Ljubljana: Studia Humanitatis.

5. Burkitt, I. (2004). The Time and Space of Everyday Life. Cultural Studies, 18 (2-3): 211-227.

6. Debord, G (2006). Društvo spektakla. Beograd: Porodična biblioteka br. 4.

7. Douglas, J. D. (Ed.) (1971). Understanding Everyday Life. Chicago: Aldin.

8. Elias, N. (1996). O procesu civilizacije - Sociogenetska i psihogenetska istraživanja. Zagreb: Antibarbarus.

9. Gardiner, M. E. (2000). Critiques of everyday life. London \& New York: Routledge.

10. Garfinkel, H. (2006). Zdravorazumsko znanje o socijalnim strukturama: dokumentarna metoda interpretacije u laičkom i profesionalnom iznalaženju činjenica. Diskrepancija, VII (11): 61-78.

11. Goffman, E. (1959). The Presentation of Self in Everyday Life. New York City: Doubleday.

12. Heller, A. (1978). Svakodnevni život. Beograd: Nolit.

13. Highmore, B. (2002). Everyday Life and Cultural Theory. London \& New York: Routledge.

14. Hromadžić, H. i Popović, H. (2019). Socijalna konstrukcija zbilje - kanonsko djelo integrativnih socioloških teorija. Konteksti, analiza, perspektive. Glasnik Etnografskog Instituta SANU, 67 (1): 33-43.

15. Kalanj, R. (1988). Henri Lefebvre kao sociolog svakidašnjeg života, u: Lefebvre Henry. Kritika svakidašnjeg života. Zagreb: Naprijed, V-XiV.

16. Katunarić, V. (2014). Predgovor, u: Simmel, Georg. Kontrapukti kulture. Zagreb: Jesenski i Turk, 7-21.

17. Kullashi, M. (1986). Ka metafilozofiji - o Lefebvreovom misaonom pothvatu. Zagreb: Filozofski fakultet.

18. Lefebvre, H. (1971). Everyday life in the modern world. New York: Harper \& Row.

19. Lefebvre, H. (1981). Misao postala svijetom. Treba li napustiti Marxa?. Zagreb: Globus.

20. Lefebvre, H. (1988). Kritika svakidašnjeg života. Zagreb: Naprijed.

21. Lukács, G. (1977). Povijest i klasna svijest. Zagreb: Naprijed.

22. Lukács, G. (1978). Predgovor, u: Heller Agnes. Svakodnevni život. Beograd: Nolit, 11-16. 
23. Marinković, D. (2019). „Epistemološka skromnost“ Pitera L. Bergera: protiv ortodoksije. Glasnik Etnografskog Instituta SANU, 67 (1): 45-62.

24. Ože (Augé), M. (2005). Prilog antropologiji savremenenih svetova. Beograd: Biblioteka XX vek.

25. Pavić, Ž. (1994). Fenomenologija i sociologija. Uvod u 'refleksivnu sociologiju'. Društvena istraživanja, 3 (10-11): 279-295.

26. Sandywell, B. (2004). The Myth of Everyday Life. Toward a heterology of the ordinary. Cultural Studies, 18 (2-3): 160-180.

27. Simić, M. (2019). Socijalna konstrukcija (post)socijalističke realnosti: etnografsko istraživanje svakodnevnog. Glasnik Etnografskog Instituta SANU, 67 (1): 121-134.

28. Simmel, G. (2014). Kontrapukti kulture. Zagreb: Jesenski i Turk.

29. Spasić, I. (2004). Sociologije svakodnevnog života. Beograd: Zavod za udžbenike i nastavna sredstva.

30. Stankovič, P. (1999). Praksa, habitus in polje. Teorija in praksa, 36 (2): 230-242.

31. Sulima, R. (2005). Antroplogija svakodnevice. Beograd: Biblioteka XX vek.

32. Štrajn, D. (2002). Refleksivna sociologija Pierra Bourdieuja, u: Bourdieu Pierre. Praktični čut II: Praktične logike. Ljubljana: Studia Humanitatis, 249-279.

33. Truzzi, M. (1968). Sociology and Everyday Life. New Jersey: Prentice-Hall.

34. Vaneigem, R. (2012). The Revolution of Everyday Life. Oakland: PM Press.

35. Yu-Cheng, L. (2012). Ethnometodology reconsidered: The practical logic of social systems theory. Current Sociology, 60 (5): 581-598. 
Prethodno priopćenje

\title{
Everyday Life: An Interface of Micro, Mezzo and Macro Theories
}

\author{
Hajrudin Hromadžić \\ University of Rijeka, Faculty of Humanities and Social Sciences, Croatia \\ e-mail: hhromadzic@ffri.hr
}

\begin{abstract}
The article is dedicated to an overview of some of the most relevant theories of everyday life. Accordingly, the paper deals with all three levels of theories of everyday life - micro (Garfinkel, Simmel, Goffman), mezzo (Berger, Luckmann, Bourdieu), and macro (Lefebvre, Debord, Vaneigem, Heller). In that context, sociology - as the central social-humanistic discipline on the issues and phenomena of everyday life - is brought into subject-methodological and interdisciplinary 'dialogue' with philosophy, and partly with anthropology and cultural studies. The paper tries to question, and even dispute, the often advocated thesis of the self-evident primacy of micro-sociological theories in research and interpretations of everyday life in relation to macro-theoretical considerations of everydayness and their relevance.
\end{abstract}

Key words: everyday life, micro-sociology of everyday life, macro-theories of everydayness. 